http://dx.doi.org/10.5597/lajam00157

\title{
ReCords of Guiana dolPhin, Sotalia guianENSIS, in the State of Ceará, Northeastern Brazil
}

\author{
Ana Carolina Oliveira de Meirelles ${ }^{1, *}$, Álvaro C. Ribeiro², Cristine P. N. Silva ${ }^{1}$ and Aldeney A. Soares Filho²
}

\begin{abstract}
The Guiana dolphin, Sotalia guianensis, is a small delphinid found in costal waters, estuaries and bays from Santa Catarina, Brazil, to Nicaragua. Strandings of Guiana dolphins were recorded systematically and opportunistically in the coast of Ceará ( 02-04 ${ }^{\circ}$ S), northeastern Brazil, from 1992 to 2005. A total of 160 single events were documented. The number of records was higher in Fortaleza Metropolitan Region than in other three surveyed areas, probably due to a more intensive survey effort. More strandings were recorded during austral winter and spring. The majority of stranded animals were adults $(48.8 \%)$. Calves were not commonly recovered and no seasonality in the strandings of calves was observed. Overall body length ranged from 95 to $208 \mathrm{~cm}$ for females and from 85 to $210 \mathrm{~cm}$ for males. A total of 49 animals (30.6\%) showed evidence of fishery interactions such as net marks and cuts. Of these, we confirmed through fisherman information the incidental catch of 13 dolphins by driftnet $(n=8)$, surface gillnet $(n=3)$ and beach seine $(n=2)$. Twenty three percent of all stranded animals showed evidences of other human interactions, like meat or fins removed, eyes removed and rostrum extracted. According to the results, Guiana dolphin strandings occurred year-round in all zones along the coast of Ceará. The incidental bycatch in fishing nets may have a negative impact on the dolphin population. The study reveals that a long-term systematic monitoring of artisanal fishing communities is necessary to evaluate the extent of the impact on the species.
\end{abstract}

Resumo: O boto-cinza, Sotalia guianensis, é um pequeno delfinídeo encontrado em águas costeiras, estuários, baías e enseadas desde Santa Catarina, Brasil, até a Nicarágua. Encalhes de boto-cinza foram registrados, sistematica e oportunisticamente, na costa do Estado do Ceará, de 1992 a 2005. Um total de 160 encalhes foi registrado. Este número foi maior na Região Metropolitana de Fortaleza do que em outras três áreas estudadas, provavelmente devido ao maior esforço de coleta. O número de eventos de encalhes foi maior no inverno e primavera. Os registros foram mais relacionados a animais adultos $(48,8 \%)$. O registro de filhotes não foi comum e não foi observada sazonalidade. O comprimento total de todos os botos variou de 95 a $208 \mathrm{~cm}$ em fêmeas e de 85 a $210 \mathrm{~cm}$ em machos. Foram encontradas evidências de interações com a pesca, como marcas de rede e facadas, em 49 animais (30,6\%). Destes, a captura acidental foi confirmada para 13 botos (através de informações dos pescadores) por caçoeira $(n=8)$, rede de espera $(n=3)$ e rede de arrasto de praia $(n=2)$. Em $23 \%$ de todos os encalhes registrados foram observadas outras evidências de interações com humanos, como a remoção de carne ou nadadeiras, extração de olhos e retirada do rostro. De acordo com os resultados, os botos encalharam durante todo o ano e em todas as áreas do estado do Ceará e a captura acidental em redes de pesca pode ser um impacto negativo nesta população de botos. Desta forma, o estudo revela que um monitoramento sistemático a longo prazo das comunidades pesqueiras torna-se necessário para avaliar a extensão do impacto destas capturas sobre a espécie.

Keywords: Guiana dolphin, Sotalia guianensis, strandings, Delphinidae, human interaction, Northeastern Brazil.

\section{Introduction}

Cetacean stranding events provide useful information for determining species occurrence, distribution and abundance (Berrow, 2001). They are also sources of information about the causes of death and provide baseline data for management and conservation actions (Mignucci-Gianonni et al., 1999; Norman et al., 2004).

The Guiana dolphin is a small delphinid found in costal waters, estuaries, and bays of Central and South America, from Santa Catarina $\left(27^{\circ} 35^{\prime} \mathrm{S}\right)$, Brazil (SimõesLopes, 1988), to Nicaragua $\left(14^{\circ} 35^{\prime} \mathrm{N}\right)$ (Carr and Bonde, 2000) and possibly Honduras (da Silva and Best, 1996). In Brazilian waters, the species occurrence has been recorded since the 1980's through strandings (e.g. Geise and Borobia, 1987; 1988; Simões-Lopes, 198713) and sighting data (e.g. Andrade et al., 1987²4; Bittencourt, 1984; Simões-Lopes, 1988). However, little information on strandings in northeast Brazil is available.

An effort to collect marine mammal stranding data in Ceará began in 1992 (see Meirelles, 2008; Meirelles et al., 2009). In 1996 the first report on cetacean strandings was published for the state (Alves Júnior et al., 1996). Previous studies based on strandings showed that mortality in Guiana dolphins was related to fishery activities (e.g. Monteiro Neto et al., 2000). The present study aims to review and update the available information on Guiana dolphin strandings at temporal and geographical

\footnotetext{
${ }^{1}$ Associação de Pesquisa e Preservação de Ecossistemas Aquáticos, Iparana, Praia de Iparana s/n, Caucaia, Ceará, Brasil, 61600-000

2 Centro de Ciências da Saúde, Universidade Estadual do Ceará, Campus do Itapery, Av. Paranjana, 1700, Fortaleza, Ceará, Brasil, 60740-903

* Corresponding author, e-mail: cameirelles@yahoo.com.br

3 SIMÕES-Lopes, P.C. (1987) Sobre a ampliação da distribuição do gênero Sotalia Gray, 1986 (Cetacea, Delphinidae) para as águas do estado de Sta. Catarina - Brasil. Pages 87-88 in Anais da 2a Reunião de Trabalho de Especialistas em Mamíferos Aquáticos da América do Sul, 4-8 August 1986, Rio de Janeiro, Brazil.

${ }^{4}$ Andrade, L., Siciliano, S. and Capistrano, L. (1987) Movimentos e atividades do boto Sotalia guianensis (Cetacea, Delphinidae) na Baía de Guanabara - Rio de Janeiro. Pages 49-56 in Anais da 2a Reunião de Trabalho de Especialistas em Mamíferos Aquáticos da América do Sul, 4-8 August 1986, Rio de Janeiro, Brazil.
} 
distribution scales, and based on sex and age-classes. We also discuss possible causes of strandings and deaths.

\section{Material and Methods}

\section{STUdy AREA}

The study area included the coast of the State of Ceará $(573 \mathrm{~km})\left(02^{\circ} 30^{\prime} \mathrm{S}, 41^{\circ} 15 \mathrm{~W}-04^{\circ} 30^{\prime} \mathrm{S}, 36^{\circ} 45^{\prime} \mathrm{W}\right)$, in northeastern Brazil (Figure 1). The coastline is largely linear and characterized by extensive sand dune fields, sandy beaches and sedimentary cliffs, which are interrupted by river mouths with mangrove forests. The divisions (or zones; Z) proposed by the National Coastal Management Plan (Brasil, 1997) were used in this study: Far Western (FWZ), Western (WZ), Fortaleza's Metropolitan Region (FMR), and Eastern (EZ) (Figure 1).

\section{Surveys and Data Collection}

Between 1992 and 1996 stranding data for Guiana dolphins was obtained through Alves-Júnior et al. (1996). From July 1996 to 1999, approximately one field trip per month was conducted in one to three different municipalities along the coast. During these surveys, awareness campaigns in the communities were conducted in order to provide information on marine mammal strandings and to create a collaborative network of volunteers to report strandings, helping us to improve the quality of marine mammals stranding information. Between 2000 and 2005, data were collected using opportunistic surveys and from reports by fishermen, government officials and tourists, most of them as part of the collaboration stranding network established during previous surveys.

The following data was collected from each stranded animal: locality and zone, species, total length (in cm; according to Norris, 1961), age class (calf, juvenile and adult) and sex of the animal. When possible, a detailed external examination of specimens was used to help assess the cause of stranding.

Age classes were defined according to body size. Animals smaller than $130 \mathrm{~cm}$ were considered calves (less than one year old), based on Rosas (2000) data on age and growth of $S$. guianensis. Adult males and females were considered animals larger than 170 and $164 \mathrm{~cm}$, respectively (see Rosas and Monteiro Filho, 2002), and individuals with body size between calves and adults were considered juveniles. Sex was determined through the position of genital slits and/or gonads observation.

\section{Data AnAlysis}

The following variables associated with the stranding events were analyzed: spatial, temporal and seasonal distributions, gender and age class (following Rosas and Monteiro Filho, 2002), condition of the carcass (as described in Geraci and Lounsbury, 1998), fisheriesrelated mortality and other human interactions. The Chisquare test $\left(c^{2}\right)$ was used $(a=0.01)$ to determine if there were significant differences in the frequency of strandings with respect to the variables described above.

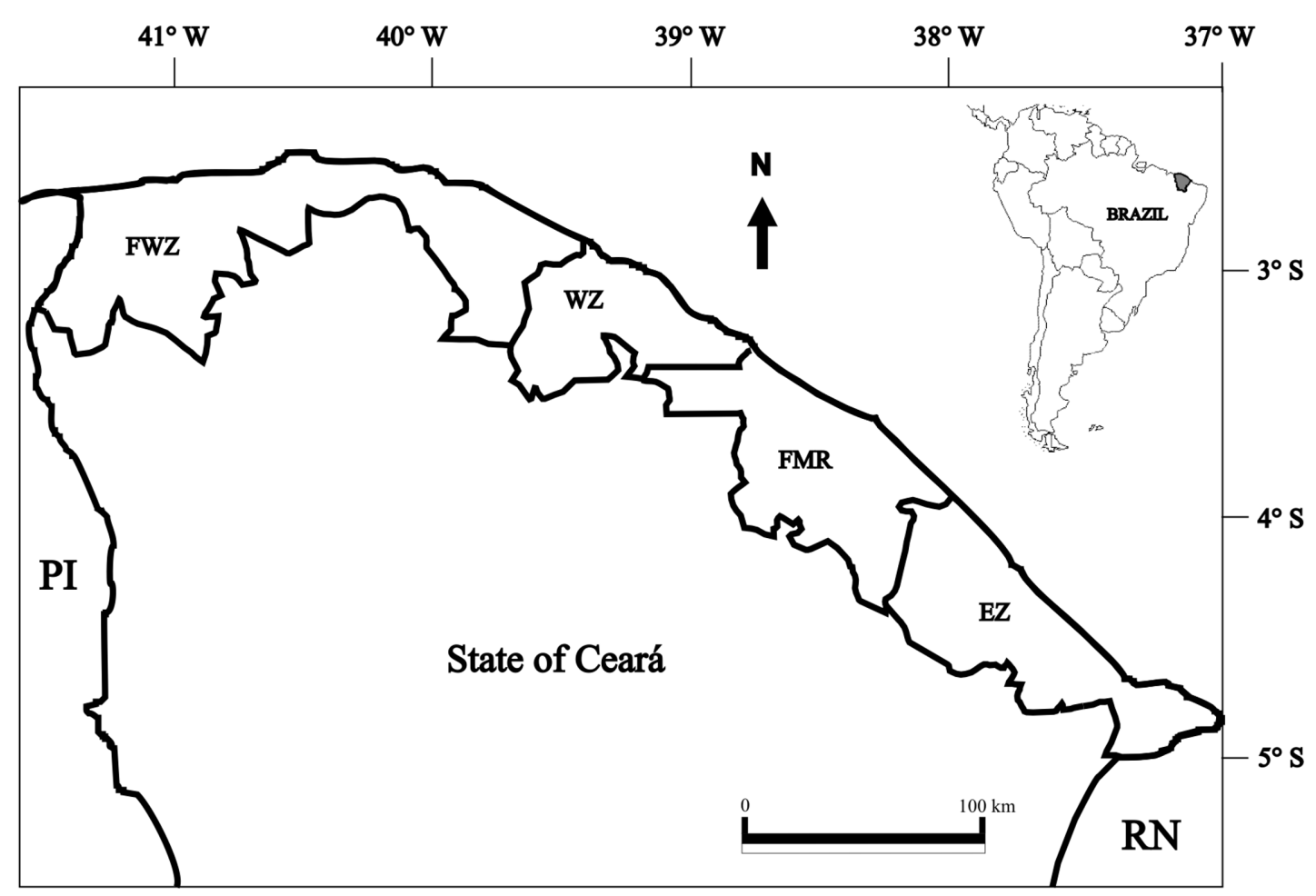

Figure 1. Map of the Ceará coast showing the zone boundaries that were used for the spatial distribution of Guiana dolphin (Sotalia guianensis) strandings. 


\section{Results}

A total of 160 S. guianensis stranding events were recorded in the study area from January 1992 to December 2005. There were no records of mass strandings. The highest number of stranded animals occurred in 1996 (Figure 2) and it was significantly higher than other years $\left(c^{2}=43.53\right.$; $p<0.01)$. The number of reported strandings was significantly different between months $\left(c^{2}=31.25 ; p<0.01\right)$, with the higher values in September and December (Figure $3)$; and between seasons ( $\left.c^{2}=23.05 ; p<0.01\right)$, with the higher events recorded during austral winter and spring. A highly significant difference in the number of strandings was observed between zones $\left(c^{2}=168.35 ; p<0.01\right)$, with the majority of events recorded in FMR (68.8\%; Figure 1). Only $5.63 \%$ of all records were reported for the FWZ.
The majority of stranding animals were related to adults (48.8\%). Calves were not commonly recorded $(9.4 \%)$ and no seasonality in the stranding of calves was observed $\left(c^{2}=0.73 ; p>0.01\right)$ (Figure 3). Juveniles represent $22.5 \%$ of recorded strandings. All age classes stranded more in FMR (Figure 4). Body length ranged from 95 to $208 \mathrm{~cm}$ for females and from 85 to $210 \mathrm{~cm}$ for males. Mean body size of adults was $187 \mathrm{~cm}(\mathrm{SD}=0.09)$. Sex was determined for $60.6 \%$ of the stranding specimens due to carcass decomposition. In strandings where sex was determined ( $\mathrm{n}=97)$, there were no significant difference in the observed number of males $(n=57)$ and females $(n=40)$ $\left(c^{2}=2.98 ; p>0.01\right)$. Four animals stranded alive: two adults, one juvenile and one calf. A high proportion of animals $(31.3 \%)$ were recovered in an advanced state of decomposition.

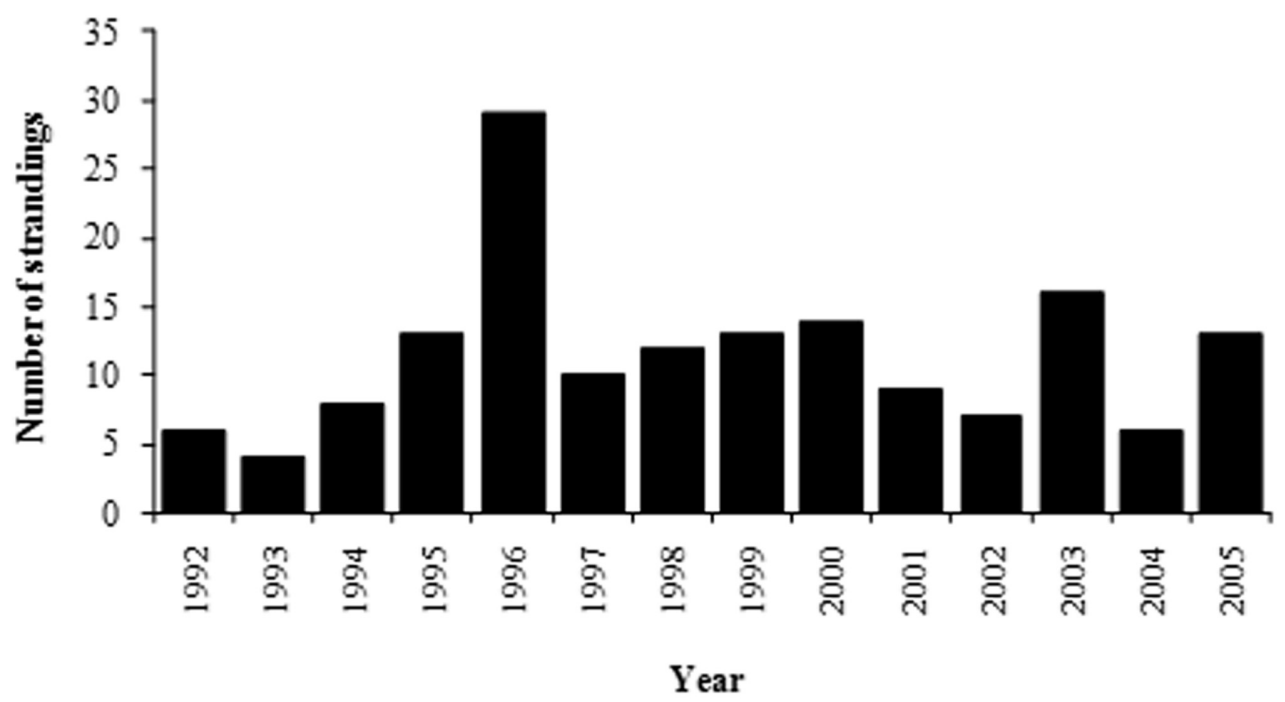

Figure 2. Distribution of S. guianensis stranding records in Ceará from 1992 to 2005.

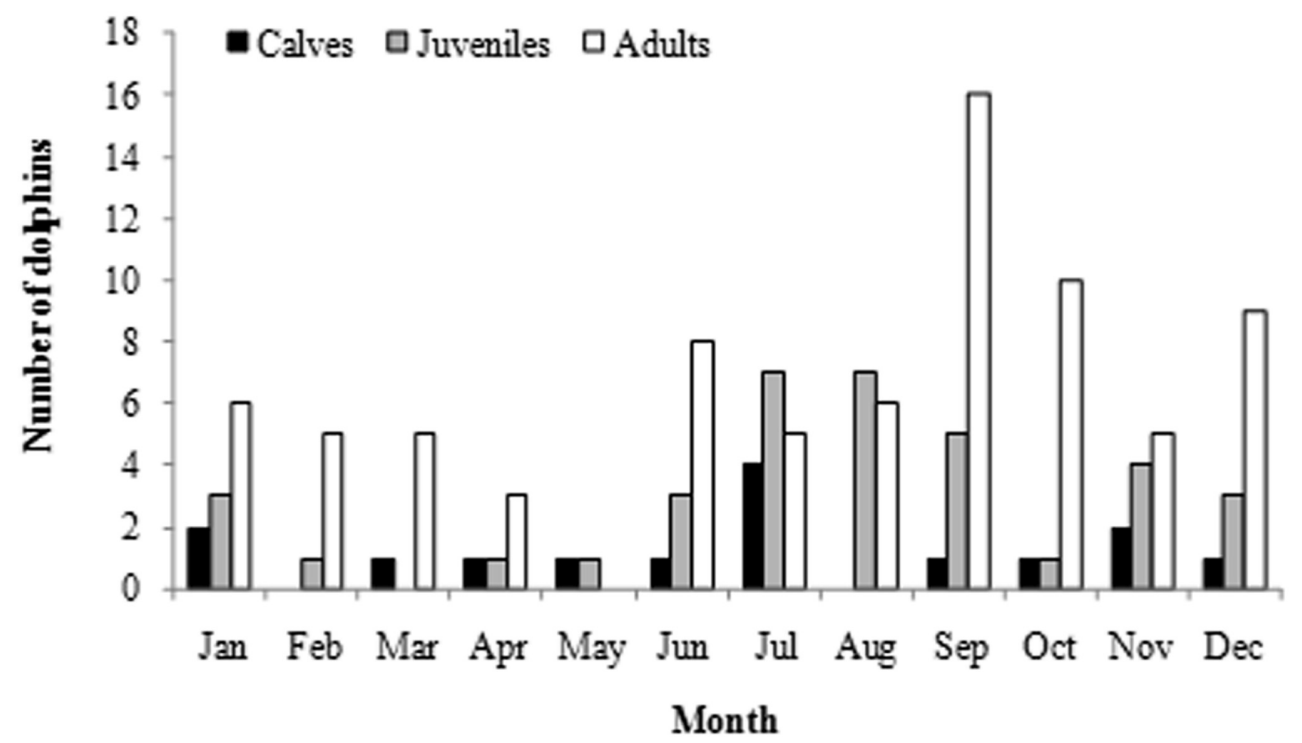

Figure 3. Distribution of S. guianensis stranding records in Ceará by month. 


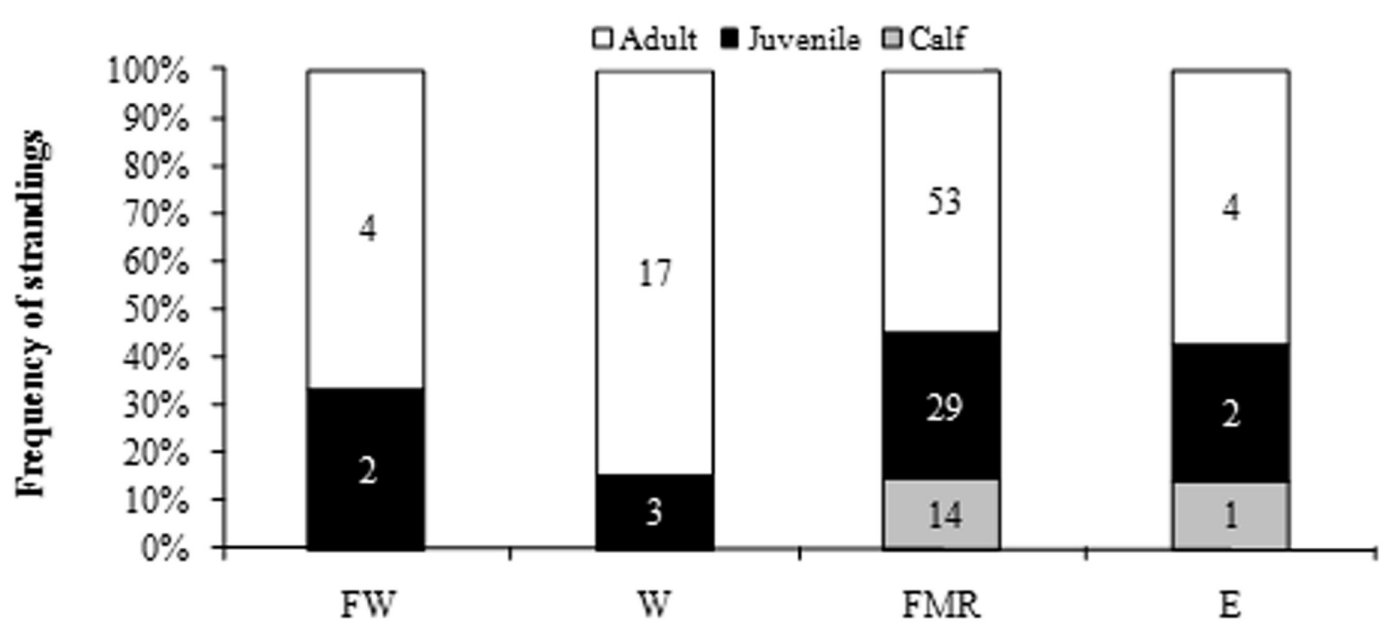

Zone

Figure 4. Frequency and number of Sotalia guianensis of all age classes that stranded in the four zones of Ceará coast from 1992 to 2005.

A total of 49 animals (30.6\%) showed evidences of fisheries interactions such as cuts and net marks. Twenty of these were adults and 26 juvenile animals. The incidental catch was confirmed for 13 animals through the fisherman information by driftnets $(n=8)$, surface gillnets $(n=3)$ and beach seines $(n=2)$. The two animals caught in beach seines were caught by the same fisherman in FMR. The animals, a lactating female $(187 \mathrm{~cm})$ and a male calf $(116 \mathrm{~cm})$ were released alive by fishermen, but stranded dead a few minutes later. The presence of narrow, linear lacerations on the epidermis of the rostrum, pectoral and dorsal fins, and tail were observed in these animals.

Twenty three percent of all stranded animals showed other evidences of human interactions, such as flesh or fins removed $(n=23)$, eyes removed $(n=9)$ and rostrum extracted $(n=5)$.

\section{Discussion}

Guiana dolphin strandings occur year-round in all zones of Ceará coast. The number of events was highest in 1996, possibly due to an increase in the carcass collection effort. More strandings being recorded in FMR does not necessarily indicate that more animals strand there. This could be a result of the location of our research base and strandings may have a higher probability of being reported in that area. However, in FMR there is a Guiana dolphin population that inhabits the Mucuripe Bay (Oliveira et al., 1995; Meirelles, 2005). In this bay the fishing harbor of Fortaleza is located, with around 480 boats, which are responsible for $14.5 \%$ of the fishery production of the state (CEPENE, 2002). Thus, we believe that these facts (presence of dolphins and fishery effort) increase the probability of dolphin incidental catches and the subsequent strandings in this zone.

The tendency for stranding events to occur in the second half of the year (July-December) may also be related to incidental bycatch, since the number of active fishing boats is higher during this time of the year, when the lobster fishery is open. The lobster fishing activity was mostly conducted with bottom gillnets (caçoeira) (CEPENE, 2002), and as reported here, this gear incidentally captured dolphins.

When compared to information on body length recorded in other areas where this species is found, $S$. guianensis seem to be larger in the Ceará coast. Di Benedito and Ramos (2004) indicated that there are no significant differences in body length-range along the Guiana dolphin distribution. However, some papers from south/southeastern Brazil indicated maximum sizes of 195-200cm (Di Benedito and Ramos, 2004; Lodi and Capistrano, 1990; Santos et al., 2003), while in the present study four animals were larger than $206 \mathrm{~cm}$. This difference can be related to the possible subdivision between Guiana dolphin populations along Brazilian coast, indicated by mitochondrial DNA analyses (Cunha et al., 2005; Caballero et al., 2010 this volume).

Incidental catches of Guiana dolphins in the State of Ceará have been reported previously by Alves-Júnior et al. (1996), Monteiro Neto et al. (2000) and Meirelles et al. (2002). We observed that these events are still common in this area despite efforts to educate the public and raise awareness of the problem. Fishermen often kill the animals that are found entangled alive, sometimes removing the meat for human consumption or bait, and frequently cutting off the fins and tail to release dolphin without damaging the fishing gear. There was no significant difference in incidental catches between mature and immature individuals recorded here, suggesting a similar vulnerability of young and adult Guiana dolphins to fisheries, as reported by Rosas (2000), in Paraná, Southern Brazil.

Interviews in coastal communities indicated that 
dolphin meat can be dried with salt and then fried for human consumption. We also observed the removal of the eyes to be used as 'lucky charms,' and teeth, which are sold to hand-crafters to produce earrings, necklaces and bracelets. Consumption of dolphin meat has already been reported in Northeastern Brazil (Tosi et al., 2007; Meirelles et al., 2009) and this custom has been indicated as a social problem, as hunger is motivating the use of cetaceans as a protein source.

Incidental catches of Guiana dolphins have been recorded along the entire Brazilian coast (Lodi and Capistrano, 1990; Simões-Lopes and Ximenez, 1990; Barros and Teixeira, 1994; Siciliano, 1994) and some efforts to avoid or reduce bycatch has been implemented, such as the use of acoustic pingers (Monteiro Neto et al., 2004) and awareness campaigns (Fragoso et al., 19965). These incidental catches may be causing negative impacts on the populations of Guiana dolphins at the State of Ceará. Long-term systematic monitoring along the coast, especially in areas of artisanal fishing communities, would be necessary to evaluate the real impact of incidental captures on these populations, and to increase our knowledge on Guiana dolphin causes of mortality. Studies to estimate population size and to determine feeding, breeding and living areas are also necessary to determine the extent of the impact and to propose conservation measures.

\section{Acknowledgements}

We sincerely thank all AQUASIS crew for their work in responding strandings and collecting data; Alberto Campos and two anonymous referees for their reviews and important suggestions to improve this manuscript; Instituto de Ciências do Mar-LABOMAR/UFC and Serviço Social do Comércio - SESC/Ceará, for important logistical support. The collection and handling of specimens was carried out under permit from Instituto Brasileiro do Meio Ambiente e Recursos Naturais Renováveis.

\section{References}

Alves Júnior, T.T., Ávila, F.J.C., Oliveira. J.A., Furtado Neto, M.A.A. And MonteIro, C. (1996) Registros de cetáceos para o litoral do Estado do Ceará, Brasil. Arquivos de Ciências do Mar 30(1-2): 79-92.

Barros, N. AND TeIXeIRA, R. (1994) Incidental catch of marine Tucuxi, Sotalia fluviatilis, in Alagoas, Northeastern Brazil. Report of the International Whaling Commission Special Issue 15: 265-268.

BERrow, S. (2001) Biological diversity of cetaceans (whales, dolphins and porpoises) in Irish waters. Pages 115-120 in NunN, J.D. (Ed) Marine biodiversity in Ireland and adjacent waters. Ulster Museum. Belfast, Northern Ireland, UK.
Bittencourt, M.L. (1984) Primeira ocorrência de Sotalia brasiliensis (bôto), Cetacea Delphinidae, para a Baía de Paranaguá, litoral paranaense, Brasil. Arquivo de Biologia e Tecnologia do Paraná 27: 95-98.

BRASIL (1997) Comissão Interministerial para os Recursos do Mar. PNGC II - Plano Nacional de Gerenciamento Costeiro II. Brasília.

Caballero, S., Trujillo, F., Vianna, J.A., Barrios-Garrido, H., Montiel, M.G., Beltrán-Pedreros, S., Marmontel, M., Santos, M.C.O., Rossi, M.R., SAntos F.R. ANd BAKER, C.S. (2010) Mitochondrial DNA diversity, differentiation and phylogeography of the South American riverine and coastal dolphins Sotalia fluviatilis and Sotalia guianensis. Latin American Journal of Aquatic Mammals 8(1-2): 69-79. http://dx.doi.org/ 10.5597/lajam00155

CARR, T. AND BONDE, R.K. (2000) Tucuxi (Sotalia fluviatilis) occurs in Nicarágua, $800 \mathrm{~km}$ north of its previously known range. Marine Mammal Science 16(2): 447-452. http://dx.doi.org/ 10.1111/j.1748-7692.2000.tb00936.x

CEPENE (2002) Boletim estatístico da pesca maritima e estuarina do Nordeste do Brasil - 2001. Centro de Pesquisa e Gestão de Recursos Pesqueiros do Litoral Nordeste - CEPENE. Tamandaré, PE, Brasil. 130 pp.

Cunha, H.A., da Silva, V.M.F., Lailson-Brito Jr, J., Santos, M.C.O., Flores, P.A.C., Martin, A.R., Azevedo, A.F., Fragoso, A.B.L., Zanelato, R.C. and Solé-Cava, A.M. (2005) Riverine and marine ecotypes of Sotalia dolphins are different species. Marine Biology 148(2): 449-457. http://dx.doi.org/10.1007/ s00227-005-0078-2

DA SILVA, V.M. AND BesT, R. (1996) Sotalia fluviatilis. Mammalian Species 527: 1-7. http://dx.doi.org/10.2307/3504117

Di Benedito, A.P.M. And Ramos, R.M.A. (2004) Biology of the marine tucuxi dolphin (Sotalia fluviatilis) in south-eastern Brazil. Journal of the Marine Biological Association of the United Kingdom 84(6): 1245-1250. http://dx.doi.org/10.1017/ S0025315404010744h

Geise, L. ANd Borobia, M. (1987) New Brazilian records for Kogia, Pontoporia, Grampus, and Sotalia (Cetacea, Physeteridae, Platanistidae, and Delphinidae). Journal of Mammalogy 68: 873875. http://dx.doi.org/10.2307/1381571

GeISE, L. AND Borobia, M. (1988) Sobre a ocorrência de cetáceos no litoral do Rio de Janeiro, entre 1968 e 1984. Revista Brasileira de Zoologia 4: 341-346.

GERACI J.R. AND LOUNSBURY V.J. (1998) Marine mammals ashore: a field guide for strandings. Texas A\&M, CD Rom version. Galveston, TX, USA.

Lodi, L. and Capistrano, L. (1990) Capturas acidentais de pequenos cetáceos no litoral norte do estado do Rio de Janeiro. Biotemas 3: 47-65.

MeIRELles. A.C.O. (2005) Aspectos da ecologia comportamental do boto cinza, Sotalia guianensis Van Bénéden, 1864 (Mammalia, Cetacea, Delphinidae), na Praia de Iracema, Fortaleza-CE. M.Sc. Thesis. Universidade Federal do Rio Grande do Norte, RN, Brazil. 113 pp.

\footnotetext{
${ }^{5}$ Fragoso, A.B.L., Azevedo, A.F., Pizzorno, J.L.A., Lailson-Brito, Jr., J., Soares, M.P., Dorneles, P.R and Gurgel, I.M.G.N. (1996) Programa de Educação Ambiental para a conservação de mamíferos aquáticos da Baía de Ilha Grande - Brasil. Page 115 in Resumenes de la $7^{\text {a }}$ Reunión de Trabajo de Especialistas en Mamíferos Acuáticos de América del Sur, 22-25 October, Viña del Mar, Chile.
} 
Meirelles, A.C.O. (2008) Mortality of the Antillean manatee, Trichechus manatus manatus, in Ceará state, north-eastern Brazil. Journal of the Marine Biological Association of the United Kingdom 88(6): 1133-1137. http://dx.doi.org/10.1017/S0025315408000817

Meirelles, A.C.O., Silva, C.P.N., Campos, A.A. and Barros, H.M.D.R. (2002) Registro do encalhe de um boto-cinza, Sotalia fluviatilis Gervais, 1853, com vestígios de nylon monofilamento em tecido cicatrizado do rostro. Arquivos de Ciências do Mar 35: 75-78.

Meirelles, A.C.O., Monteiro Neto, C., Martins, A.M.A., Costa, A.F., Barros, H.M.D.R. AND Alves, M.D.O (2009) Cetacean strandings in Ceará coast, north-eastern Brazil (1992-2005). Journal of the Marine Biological Association of the United Kingdon 89(5): 10831090. http:// dx.doi.org/10.1017/S0025315409002215

Mignucci-Giannoni, A., Pinto-Rodriguez, B., VelascoEscudeiro, M., Montoya-Ospina, R.A., Jimenez-Marrero, N.M., Rodriguez-Lopez, M.A., Williams, E.H. Jr. And Odell, D.K. (1999) Cetacean strandings in Puerto Rico and the Virgin Islands. Journal of Cetacean Research and Management 1: 191-198.

Monteiro Neto, C., Alves-Júnior, T.T., Ávila, F.J.C., Campos, A.A., Costa, A.F., Silva, C.P.N. And Furtado Neto, M.A.A. (2000) Impact of fisheries on the tucuxi (Sotalia fluviatilis) and roughtoothed dolphin (Steno bredanensis) populations off Ceará State, northeastern Brazil. Aquatic Mammals 26(1): 49-56.

Monteiro Neto, C., Ávila, F.J.C., Alves-Jr, T.T., Araújo, D.S., Campos, A.A., Martins, A.M.A., Parente, C.L., Furtado Neto, M.A.A. AND LIEN, J. (2004) Behavioral Responses of Sotalia fluviatilis (Cetacea, Delphinidae) to acoustic pingers, fortaleza, brazil. Marine Mammal Science, 20(1): 145-151. http://dx.doi.org/ 10.1111/j.1748-7692.2004.tb01145.x

NoRRIS, K. S. (1961) Standardized methods for measuring and recording data on the smaller cetaceans. Journal of Mammalogy 42(4): 471-476. http://dx.doi.org/10.2307/1377364

Norman, S.A., Bowlby, C.E., Brancato ,M.S., Calambokidis, J., Duffield, D., Gearin, P.J., Gornall, T.A., Gosho, M.E., Hanson,
B., Jefries, S.J., Lagerquist, B., Lambourn, D.M., Mate, B., NorberG, B., Osborne, R.W., RASH, J.A., RiEMER, S. AND SCORdino, J. (2004) Cetacean strandings in Oregon and Washington between 1930 and 2002. Journal of Cetacean Research and Management 6: 87-99.

Oliveira, J.A., Ávila, F.J.C., Alves-Júnior, T.T., Furtado Neto, M.A.A. and Monteiro Neto, C. (1995) Monitoramento de boto cinza, Sotalia fluviatilis (Cetacea: Delphinidae) em Fortaleza, estado do Ceará, Brasil. Arquivos de Ciências do Mar 29(1-2): 28-35.

Rosas, F.C.W. 2000. Interações com a pesca, mortalidade, idade, reprodução e crescimento de Sotalia guianensis e Pontoporia blainvillei (Cetacea, Delphinidae e Pontoporiidae) no litoral sul do Estado de São Paulo e litoral do Estado do Paraná, Brasil. Ph.D. Thesis, Universidade Federal do Paraná. Curitiba, PR, Brazil. 145 pp.

Rosas, F.C.W., AND MonteIro FiLHO, E.L.A. (2002) Reproduction of the estuarine dolphin (Sotalia guianensis) on the coast of Paraná, southern Brazil. Jornal of Mammalogy 83(2): 507-515. h t t p : / / d x.d o i.org / $10.1644 / 1545$ 1542\%282002\%29083\%3C0507:ROTEDS\%3E2.0.CO;2

Santos, M.C.O., Rosso, S. and Ramos, R.M.A. (2003) Age estimation of marine tucuxi dolphins (Sotalia fluviatilis) in southeastern Brazil. Journal of the Marine Biological Association of the United Kingdom 83: 233-236. http:/ / dx.doi.org/10.1017/ S0025315403007021h

Siciliano, S. (1994) Review of small cetaceans and fishery interactions in the coastal waters of Brazil. Report of the International Whaling Commission Special Issue 15: 241-250.

SIMÕES-LOPES, P. (1988) Ocorrência de uma população de Sotalia fluviatilis Gervais, 1853 (Cetaceae, Delphinidae) no limite sul da sua distribuição, Santa Catarina, Brasil. Biotemas 1: 57-62.

Tosi, C.H., Magalhães, A.F. AND GarRI, R.G. (2007) Can the estuarine dolphin (Sotalia guianensis) be classified as vulnerable species in Maranhão Coast, Northeastern Brazil? Whales Alive 7: $1-3$. 